\title{
Diagnostic of Primary Ciliary Dyskinesia: guidelines to obtain appropriate ciliate cell samples
}

\author{
S Blanchon ${ }^{1 *}$, L Bassinet $^{2}$, A Clément ${ }^{2}$, A Coste $^{3}$, E Escudier $^{4}$, C Thumerelle ${ }^{5}$ \\ From First International Cilia in Development and Disease Scientific Conference (2012) \\ London, UK. 16-18 May 2012
}

\section{Background}

Primary Ciliary Dyskinesia (PCD) is a rare inherited disease $(\sim 1 / 20,000)$, characterized by ciliary structure/function abnormalities, responsible for impaired muco-ciliary transport, leading to recurrent upper and lower airways infections early in life and infertility. The diagnosis is confirmed on ciliate cell samples, collected by nasal and/or bronchial endoscopy. Patients usually need several samples, due to difficulties to get reliable results, especially during respiratory tract infections which are frequent in PCD. We created national guidelines aimed at obtaining the more efficient quality of ciliate cell samples for children and adults.

\section{Methods}

A multicentric working group, created in 2009 within the French National Centre for Rare Respiratory Diseases, elaborated guidelines. It includes experimented ear-nosethroat and pulmonologist physicians, adults and children physicians, pathologists, technicians, involved in PCD diagnosis and care.

\section{Results}

Improvement of sample quality requires 3 main duties: (i) 1 month free of respiratory tract infection or previous antibiotherapy (ii) preventing haemorrhagic complications (iii) a well-organized consignment to laboratory. We describe a step by step precise procedure for brushing (ciliary beat analysis) and biopsy (ultrastructural analysis) from nose and bronchus. The needed equipment for all procedures is provided, with references and seller's contacts.

\footnotetext{
* Correspondence: sylvainblanchon@hotmail.com

'Dept Pediatric Pulmonology, Hôpital Trousseau, France

Full list of author information is available at the end of the article
}

\section{Conclusion}

Based on the French Reference Centre experience and on international recommendations, these new guidelines are very helpful to harmonize procedures and obtain efficient and usable ciliate cells sample. Application of these guidelines is an essential step to improve patient's management, while reducing the number of samples and the delay to PCD diagnosis.

\section{Author details}

'Dept Pediatric Pulmonology, Hôpital Trousseau, France. ${ }^{2}$ Dept Pulmonary, Hôpital Inter-Communal, Creteil, France. ${ }^{3}$ ENT Department, Hôpital InterCommunal and Hôpital Henri Mondor, Creteil, France. ${ }^{4}$ Dept Medical Genetic and Embryology, Hôpital Trousseau, France. ${ }^{5}$ Dept Pediatrics, Hôpital Regional Universitaire, Lille, France.

Published: 16 November 2012

doi:10.1186/2046-2530-1-S1-P4

Cite this article as: Blanchon et al: Diagnostic of Primary Ciliary

Dyskinesia: guidelines to obtain appropriate ciliate cell samples. Cilia 2012 1(Suppl 1):P4.

Submit your next manuscript to BioMed Central and take full advantage of:

- Convenient online submission

- Thorough peer review

- No space constraints or color figure charges

- Immediate publication on acceptance

- Inclusion in PubMed, CAS, Scopus and Google Scholar

- Research which is freely available for redistribution

\section{Biomed Central}

๑ 2012 Blanchon et al; licensee BioMed Central Ltd. This is an Open Access article distributed under the terms of the Creative Commons Attribution License (http://creativecommons.org/licenses/by/2.0), which permits unrestricted use, distribution, and reproduction in any medium, provided the original work is properly cited. 